\title{
THE POSSIBILITIES AND LIMITATIONS OF CHEMICAL GENERATORS OF ELECTRICITY.
}

\author{
BY FRANCIS B. CROCKER.
}

Electro-chemistry seems less generally and less clearly understood than any other branch of electricity of equal importance. The facts concerning the dynamo, motor, telegraph and telephone are widely and definitely known; but there are ideas, statements and claims in regard to batteries which are further from the truth, more prevalent and go longer without being contradicted than any other collection of errors that I can call to mind.

Primary batteries have not received the attention in this country that they have abroad, particularly in England, where the successful or unsuccessful attempt to float a new primary battery company is a matter of almost weekly occurrence. Nevertheless the subject is a sufficiently important one, and the false ideas of which I have spoken have spread so far beyond the quacks, to whom such ideas are usually confined, that the subject deserves more study than it usually receives, particularly from the scientific standpoint.

Electromotive Force.-The electromotive force which a given battery or combination of materials will develop is the first and most important question in electro-chemistry. Of course the best and surest way to arrive at this E. M. F. is to determine it by actual experiment with a voltmeter, or, still better, by comparison with a standard cell. There are, however, many times when the materials or instruments are not at hand, and a calculation or predetermination of the E. M. F. is very convenient.

The formula for calculating the E. M. F. is obtained by assuming that the electrical energy of the given chemical combination is equal to the heat energy which the same combination is capable of producing, or $E C=4.16 C a H$, that is, volts multiplied by coulombs is equal to the coulombs multiplied by the electro- 
chemical equivalent, i.e., the weight of material required per coulomb and that by the heat produced by one gramme of the material. The electrical equivalent of heat 4.16 is introduced to reduce both members of the equation to an electrical basis. Cancelling the $C$ in both members, we have $E=4.16 a H$, in which $E$ is the E. M. F. in volts, $a$ is the electro-chemical equivalent (grammes per coulomb), and $H$ is the number of heat units (gramme-degrees Cent.) produced per gramme of material by the given chemical combination. The values of $a$ and $H$ are given for most materials in electrical and chemical books of reference, and the calculation is a very simple one, nevertheless this formula and the principle involved in it are not generally understood and are very seldom used. The equation deduced above is that ordinarily given, but what I have found to be a more convenient form of it is obtained by assuming that $E=1$, giving $a$ its value for hydrogen (.00001035). Solving with respect to $H$ we have $H=23300$, which means that 23300 is the number of heat units per equivalent corresponding to one volt, and all that is necessary to find the volts of any given chemical combination is to divide the number of heat units per equivalent (which is the form they are almost always given in) by 23300 and the quotient is the E. M. F. in volts. For example, to obtain the E. M. F. which zinc and free chlorine will develop divide 48,600 (which is the number of heat units produced by the combination of one equivalent of zinc with one of chlorine as given by Thomsen) by 23,300 , and the result 2.09 is certainly very close to 2.11 , the actual value obtained by experiment. In the same way the E. M. F. of other combinations of materials may be predetermined, but it should be always borne in mind that the heat of combination corresponding to one equivalent of the material should be taken and not necessarily that corresponding to one atom; as for example in the case of zine, the heat per atom (65 grammes) is 97,200 which has to be divided by 2 to reduce it to one equivalent because zinc is a dyad and takes two atoms of chlorine, which is a monad. In the case of monad metals like sodium, potassium and silver the figures may be taken just as they are given in the tables. Mistakes very frequently arise is this way; in fact I do not think I ever saw a table of electro-chemical equivalents in which this point was correctly introduced in every case.

In order to test the practicability and accuracy of calculating E. M. F., as well as to obtain reliable results and full data for 
their own value, I determined the E. M. F. given by thirteen of the most important metals in combination with free chlorine, bromine and iodine, and the results are given in tables $\mathrm{A}, \mathrm{B}$ and $\mathrm{C}$ respectively. In table $\mathrm{D}, \mathrm{I}$ have averaged the results and placed them side by side with the results obtained by calculation. The agreement between the two sets of figures is not perfect by any means, but when it is remembered how the E. M. F. of a cell will change one or two-tenths of a volt on apparently the slightest provocation, I think the figures are strikingly close, more so than I expected to find them. In more than half of the cases the difference is less than one-tenth of a volt, and the average difference is only slightly more than that There has been no warping or coaxing of the figures to secure uniformity. The results are given just as they came. If figures were picked ont from the different observations, it would be possible to obtain almost perfect agreement between the calculated and the determined, as one may see by looking over the tables.

In regard to the experimental results as given in tables $\mathrm{A}, \mathrm{B}$ and C, I may state that all the metals and salts used were chemically pure, with the exceptions of the metals magnesium and aluminium, and these were of a very good quality. Pure carbon plates were used for the negative plate, but platinum was also tried and gave substantially the same results. The E. M. F. was measured by a Thompson reflecting galvanometer (by Elliott) using two independent standard Daniell cells. One fact which strikes one in looking over the tables $\mathrm{A}, \mathrm{B}$ and $\mathrm{C}$, is that the $\mathrm{E}$. M. F. is not very greatly affected by the solution; a certain metal gives about the same result in one chloride as in another, and the same is true of the bromides and iodides. In table $\mathbb{E}$, I have given the E. M. F. obtained by substituting different metals for the zinc in a Daniel's cell, but these results being from only one series of observations are probably not so reliable as those in the preceding tables.

In the remaining table I have collected in condensed form the principal facts in regard to batteries in which zinc is used as the electro-positive material with the most important electro-negative or depolarizing materials. The facts in regard to metallic zinc, which hold good in all cases in which it is used (no matter what the other material is), are given on a horizontal line with zinc. Below this the facts in regard to each particular combination are 
given opposite the depolarizer. For example, the data of a zinc and chlorine battery are given on a horizontal line with chlorine, of a zinc and nitric acid (Bunsen) battery on a line with nitric acid.

\section{TABLE A.}

E. M. F. produced by different Metals in Combinations with Free Chlorine in Solutions of -.

\begin{tabular}{|c|c|c|c|c|c|c|c|}
\hline & $\begin{array}{l}\text { Magnesium } \\
\text { Chloride. }\end{array}$ & $\begin{array}{c}\text { Zine } \\
\text { chlor- } \\
\text { ide. }\end{array}$ & $\begin{array}{c}\text { Zine } \\
\text { Chlor- } \\
\text { ide. }\end{array}$ & $\begin{array}{l}\text { Zinc } \\
\text { chlor. } \\
\text { ide. }\end{array}$ & $\begin{array}{l}\text { Hydro- } \\
\text { Chloric } \\
\text { Acid. }\end{array}$ & $\begin{array}{c}\text { Com- } \\
\text { mon. } \\
\text { salt. }\end{array}$ & $\begin{array}{c}\text { Aver- } \\
\text { age. }\end{array}$ \\
\hline Magnesium & $2.83 \quad 2.65$ & 2.65 & & & $3.2-3.15$ & 2.85 & 3.1 \\
\hline Zinc. & 2 & 2.20 & 2.13 & 2.11 & 2.20 & 2.18 & 2.11 \\
\hline Cadmium & & 1.94 & & 1.86 & 1.98 & 1.93 & 1.9 \\
\hline Aluminium. . & 1.75 & 2.04 & 1.88 & & 2.02 & 1.98 & 2. \\
\hline Iron........ & & 1.60 & 1.56 & 1.5 & 1.67 & 1.68 & 1.6 \\
\hline Cobalt. & & 1.43 & 1.43 & 1.41 & 1.50 & 1.45 & 1.43 \\
\hline Nickel. & & 1.33 & & 1.27 & 1.40 & 1.33 & 1.33 \\
\hline Tin. & 1.50 & 1.70 & 1.6 & 1.57 & 1.68 & 1.66 & 1.61 \\
\hline Lead & & 1.63 & 1.62 & 1.60 & 1.68 & 1.65 & 1.63 \\
\hline Copper.. & & 1.31 & 1.30 & 1.29 & 1.37 & 1.34 & 1.32 \\
\hline Silver & & 1.11 & 1.12 & 1.13 & 1.15 & 1.10 & 1.11 \\
\hline Ant & & 1.20 & 1.23 & 1.25 & 1.25 & 1.08 & 1.22 \\
\hline Bismuth.......... & & 1.29 & 1.25 & 1.20 & 1.27 & 1.19 & 1.21 \\
\hline
\end{tabular}

\section{TABLE B.}

E. M. F. of different Metals with Free Bromine in solutions of

\begin{tabular}{|c|c|c|c|c|c|c|}
\hline & $\begin{array}{l}\text { Hingnets. } \\
\text { Mro- } \\
\text { mide. }\end{array}$ & $\begin{array}{c}\text { Nickel } \\
\text { Bromide. }\end{array}$ & $\begin{array}{c}\text { Po ass. } \\
\text { Bro- } \\
\text { mide. }\end{array}$ & $\begin{array}{l}\text { Hydro- } \\
\text { Bromic. } \\
\text { Acid. }\end{array}$ & $\begin{array}{l}\text { Magnes. } \\
\text { Brminide } \\
\text { weak. }\end{array}$ & Average \\
\hline Magnesium. & 2.55 & 2.45 & 2.51 & 2.7 & 2.57 & 2.56 \\
\hline Zine. & 1.84 & 1.78 & 1.82 & 1.79 & 1.85 & 1.69 \\
\hline Cadmium..... & 1.6 & 1.54 & 1.62 & 1.57 & 1.61 & 1.58 \\
\hline Aluminium. . & 1.5 & 1.46 & 1.47 & 1.46 & 1.6 & 1.53 \\
\hline Iron......... & 1.22 & 1.25 & 1.31 & 1.26 & 1.33 & 1.3 \\
\hline Cobalt & 1.1 & 1.02 & 1.05 & 1.06 & 1.13 & 1.05 \\
\hline Nickel. & .8 & $.85-.8$ & .8 & .87 & .94 & .85 \\
\hline Tin. & 1.12 & 1.31 & 1.3 & 1.25 & 1.27 & 1.3 \\
\hline Lead & 1.4 & 1.27 & 1.33 & 1.28 & & 1.33 \\
\hline Copper.... & 1.05 & .96 & 1.01 & .99 & 1.03 & 1.02 \\
\hline Silver. . & .97 & .94 & .97 & .95 & .93 & .95 \\
\hline Anti & .99 & .73 & .71 & .87 & .97 & .8 \\
\hline Bismuth. & .92 & .9 & .96 & .88 & .92 & .92 \\
\hline
\end{tabular}




\section{TABLE C.}

E. M. F. of different Metals with free Iodine in solutions of -

\begin{tabular}{|c|c|c|c|c|}
\hline & $\begin{array}{l}\text { Magnes. } \\
\text { Iodide. }\end{array}$ & $\begin{array}{c}\text { Zlnc } \\
\text { Iodide. }\end{array}$ & $\begin{array}{l}\text { Potass. } \\
\text { Iodide. }\end{array}$ & Average \\
\hline Magnesium & 2.02 & & 2.00 & 2.01 \\
\hline Zinc & 1.35 & 1.23 & 1.29 & $1.2 \overline{5}$ \\
\hline Cadmium. & 1.12 & 1.12 & 1.13 & 1.12 \\
\hline Aluminium. & .92 & .83 & .87 & .88 \\
\hline Iron......... & .69 & .6 & .74 & .68 \\
\hline Cobalt............. & .6 & .42 & .5 & .51 \\
\hline Nickel. $\ldots \ldots \ldots \ldots \ldots \ldots \ldots \ldots \ldots \ldots$ & & .35 & .37 & .36 \\
\hline Tin............... & & .72 & .69 & .71 \\
\hline Lead............... & & .82 & .85 & .83 \\
\hline Copper..................... & .63 & .67 & .62 & .64 \\
\hline$\ldots \ldots, \ldots: \cdots, \ldots, \ldots, \cdots$, & .65 & .67 & .64 & .65 \\
\hline Antimony $\ldots \ldots \ldots \ldots \ldots \ldots \ldots \ldots$ & .41 & .47 & .46 & .44 \\
\hline Bismuth..... $\ldots . . .$. & .39 & .46 & .42 & .43 \\
\hline
\end{tabular}

\section{TABLE D.}

Comparison of the E. M. F. Calculated from the Heat of Combination and the E. M. F. determined by experiment.

\begin{tabular}{|c|c|c|c|c|c|c|}
\hline Metals. & \begin{tabular}{|} 
Combin- \\
Ing with \\
Chl'rine \\
Calc.
\end{tabular} & Determ. & $\begin{array}{l}\text { Bro- } \\
\text { mine } \\
\text { Calc. }\end{array}$ & Determ. & $\begin{array}{l}\text { Iodine } \\
\text { Calc. }\end{array}$ & Determ \\
\hline Magnesium $\ldots \ldots \ldots \ldots \ldots \ldots \ldots \ldots$ & 3.24 & 3.1 & & & & \\
\hline Zinc $\ldots \ldots \ldots \ldots \ldots \ldots \ldots \ldots$ & 2.09 & 2.11 & 1.68 & 1.79 & 1.05 & 1.25 \\
\hline Cadmium. & 2. & 1.9 & 1.58 & 1.58 & .97 & 112 \\
\hline Aluminium. & 2.3 & 2. & 1.7 & 1.53 & 1.00 & .88 \\
\hline Iron. & 1.75 & 1.6 & 1.5 & 1.3 & .85 & .68 \\
\hline Cobalt & 1.64 & 1.43 & & & & \\
\hline ............. & 1.57 & 1.33 & & & & \\
\hline Tin $\ldots \ldots \ldots \ldots \ldots \ldots \ldots \ldots \ldots \ldots \ldots \ldots$ & 1.71 & 1.61 & 1.5 & 1.3 & & \\
\hline Lead......... & 1.76 & 1.63 & 1.38 & 1.33 & .85 & .83 \\
\hline Copper.... . . . . . . . . . & 1.4 & 1.32 & 1.07 & 1.02 & .69 & .64 \\
\hline Silver....... & 1.25 & 1.11 & .97 & .95 & .59 & .65 \\
\hline Antimony & 1.3 & 1.22 & & & & \\
\hline Bismuth. .... & 1.3 & 1.21 & & & & \\
\hline
\end{tabular}

\section{TABLE E.}

F. M. F. produced by different Metals substituted for the Zinc in a Daniels cell.

\begin{tabular}{|c|c|c|c|}
\hline Metals. & Volts. & Merals. & Volts. \\
\hline Zinc & 1.08 & Lead. . & .58 \\
\hline 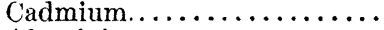 & .79 & Copper. & .07 \\
\hline Aluminium ... & .65 & Silver. & -.02 \\
\hline Iron & .64 & Antimony. & .09 \\
\hline Cobalt............. & .40 & Bismuth $\ldots \ldots \ldots \ldots \ldots \ldots$ & .17 \\
\hline Nickel. & .1 & & \\
\hline
\end{tabular}




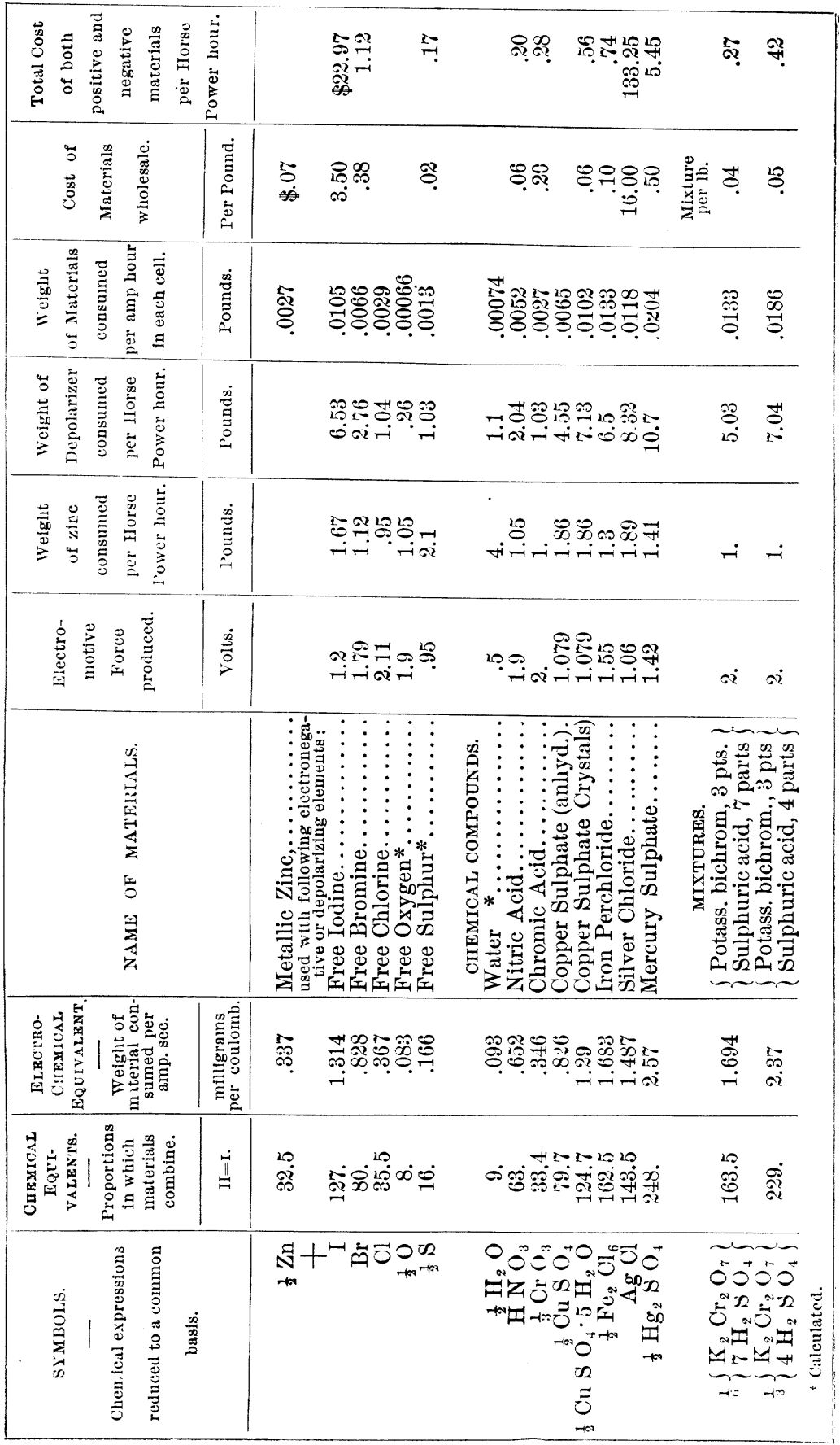


For convenience the table is divided into two parts; the lefthand side contains the purely scientific data, and the right-hand portion contains the practical facts.

In the first column of the first part is given the chemical symbols reduced to a common basis, any one of the expressions being chemically equivalent to any other. For example, one-half atom of zine $\left(\frac{1}{2} \mathrm{Zn}\right)$ requires one atom of chlorine $(\mathrm{Cl})$, or one-half atom of oxygen $\left(\frac{1}{2} \mathrm{O}\right)$, or one-third molecule of chromic acid $\left(\frac{1}{3} \mathrm{Cr}_{2} \mathrm{O}_{3}\right)$, or one-sixth of the mixture of one molecule or potassium bichromate and seven molecules of sulphuric acid $\left(\frac{1}{6}\left[\mathrm{~K}_{2} \mathrm{Cr}_{2} \mathrm{O}_{7}+7 \mathrm{H}_{2} \mathrm{SO}_{4}\right]\right)$, and so on.

In the second column I give the chemical equivalents which are simply the proportions by weight required of the different materials. That is, when we use 32.5 grammes of zinc (hydrogen being assumed as one gramme), we require 35.5 grammes of chlorine, or 33.4 grammes of chromic acid, and so on.

The third column contains the electro-chemical equivalents, which are really exactly the same and directly proportional to the combining weights in the previous column, but are reduced to an electric basis of so many milligrames per coulomb. To convert these figures into grammes per ampère hour simply multiply by 3.6 .

In the first column of the second part of the table is given the E. M. F. of each combination, all of which with the exception of oxygen, sulphur and water are determined by experiment, most of them being well known and accepted values. In the case of oxygen, sulphur and water the E. M. F. is calculated as explained above and is merely given for comparison. No actual battery corresponding to these materials exists.

In the second column on the right-hand side, is given the number of pounds of zine required per horse-power hour in the case of each combination. For example, a zine and copper sulphate (Daniell) battery, requires 1.86 pounds of zinc per horsepower hour of electrical energy produced.

In the next column I give the weight of depolarizer required per horse-power hour in the case of each combination. For example, a battery requires 5.05 pounds of the mixture of three parts of potassium bichromate, and seven parts of sulphuric acid, which is about the ordinary strong bichromate solution for porous cell batteries. Of course the water required for the solution is not considered here or in any of the other figures of the tables, 
because it cost nothing and serves merely as a medium of electrical action; but if the total weight of solution is desired, the weight of water must be added.

The weight of the different materials consumed per ampère hour is given in the next column. These figures are obtained directly from the electro-chemical equivalents in the third column by dividing by 125 ; in fact, they are simply the electro-chemical equivalents in pounds per ampère hour.

It should always be carefully noted that the weight consumed per ampire hour is that required in each cell in series, whereas in the case of horse-power hours the weight given in the table is the total weight used, no matter how many cells there are or how they are arranged.

In the next to the last column is given the wholesale cost per pound of the different materials. These prices are of course very difficult to fix, because they depend upon the market and vary greatly upon the quantities bought; but the prices I have here are very low and ordinary consumers would have to pay twice as much in most cases; they give, however, some idea of costs.

In the last column I have given the cost of both materials, zinc and depolarizer, added together. I have not here considered the values of the products, because it is very difficult to estimate the cost of collecting and utilizing residues. In the case of silver chloride the silver resulting from the action would, of course, be worth a large portion of the cost of the original chloride.

One of the interesting points which this table shows is the total weight required by horse-power hour. For example, .95 pound of zinc and 1.04 pounds of chlorine, making a total of almost exactly 2 pounds, would produce one horse-power of current for one hour, if all of the chemical energy could be converted into electric energy.

This brings up the question of how large a percentage of the chemical energy can be utilized, or, in other words, the efficiency of chemical generators. This efficiency is higher, I think, than it is generally supposed to be. I have no exact figures upon this point, but I have tested several times the weight of zinc consumed compared with the theoretical amount, and I have found that even in a plunge battery, where the bichromate solution was directly in contact with the zinc and the opportunity for local action was a maximum, that the zine efficiency was as high as 75 per cent., and in one case 80 per cent. In a porous cell bat- 
tery with amalgamated zinc, where there was little or no cause for local action, I believe the zinc efficiency would be as high as 90 per cent., and I should not be surprised to find it as high as 96 or 97 per cent.

The efficiency of the depolarizer is generally lower than that of the zinc, because there is generally a good deal of chemical energy left in the solution after it is too weak for satisfactory work. The efficiency of the bichromate solution in the plunge battery I have just referred to was only about 45 per cent. of the total theoretical power. But this is very low, because the solution has to be weak in acid in account of being used in contact with the zinc. In the case of a copper sulphate battery, where the crystals of sulphate are often almost entirely used up, I think the efficiency would be as high as 80 or 90 per cent. The efficiency I speak of here is simply the chemical efficiency in the battery; the fall of potential in the battery due to its internal resistance compared to the external is another loss which has to be added to the chemical loss in determining the total efficiency.

The possibilities of chemical generators are therefore almost infinite, since it requires theoretically a total of only 2 pounds of zinc and chlorine, and 2 pound of zine and chromic acid per horse-power hour, and since the efficiency of batteries can easily be made as high as 75 per cent. it follows that less than three pounds of material is actually required per horse-power hour; but unfortunately the water for the solution, the containing vessel, electrodes, etc., are so heavy that the total weight is very many times greater. The possible and the actual battery are thus very far apart. If we use metals of higher chemical affinity and E. M. F. than zinc, the theoretical weight of material required is even less; only one pound total of chlorine and magnesium are required per horse-power hour, with metallic sodium and free chlorine having a calculated E. M. F. of 4 volts it would only take about .8 pound per horse-power.

The easiest and best solution of the problem, however, does not seem to be the use of more powerful metals than zinc. The latter is powerful enough; it only takes, as we have seen, about one pound of it per h. p. hour with nitric acid, chromic acid or bichromate solution, and less than two pounds with copper sulphate. The opportunity for improvement seems to lie more in the direction of perfecting the general form of batteries. The apparatus is at fault, not the chemical action. Moreover, zinc 
is about as high on the electro-positive scale as it is safe to go so long as water is present. Even in the case of zinc its affinity for oxygen is greater than that of hydrogen, it is therefore only by tolerance, so to speak, that zinc remains passive in the presence of water. If it is not properly amalgamated, or if the solution is too strong, local action does occur. If, in place of zinc, we use any more electro positive metal these troubles are aggravated; with magnesium, for example, there are only very few solutions in which it will stand without great local action. Metals of still higher power, such as sodium, cannot be used at all in presence of water. Jablochkoff has, I believe, made cells in which sodium is used with damp cloth, but this can hardly be considered as water.

The proper way to use metals of great chemical energy would seem to be with liquids which do not contain any oxygen, but unfortunately such solutions are not generally good conductors. Another possible plan is to employ a fused electrolyte, but this involves the serious difficulty of maintaining it in the fused state.

So far as I can see, zinc is a very satisfactory positive material for batteries. After all it is cheaper than any other metal except iron. It is a sufficiently good conductor and less dirty and liable to corrosion than almost any other metal; it is also, as I have just shown, about as high on the electro-positive list as is safe to go.

The electro-negative materials on the other hand leave far more to be desired. They are generally expensive, very troublesome to handle, and introduce that quality of simple dirtiness, to which no other name can be applied, and which is realiy the most serious objection to batteries. The electro-negatives will, however, do the work, and as we have seen it actually requires very little weight to give a great deal of power, if the materials could only be used in a more perfect manner than at present. That seems to be the thing to hope for. Another serious difficulty with batteries is their high internal resistance. A dynamo can easily be made to give 100 volts with a thousandth or a few ten thousandths of an ohm internal resistance, hence their great output; but a primary battery capable of giving 100 volts with only one thousandth of an ohm internal resistance would probably fill this house.

In this connection it will be interresting to consider how many cells of ordinary gravity battery are required to give one horsepower of current. Each cell will give one volt and not more 
than half an amp re under normal conditions, hence each cell furnishes half a watt or about 1,500 cells to the horse-power! These cells would, however, give that power for a long time. But the fact remains that this very large number is required to produce the power which a dynamo not much larger than one's hat will generate.

In conclusion, I would say that I am by no means a skeptic in regard to chemical generators of electricity; the possibilities are very, very great, as I have shown. But these possibilities do not seem to have been brought to reality in a very perfect manner as yet. But batteries, even in the imperfect state in which they exist to-day, have their useful and legitimate function. A Leclanché cell is exceedingly well adapted to ringing electric bells intermittently and to telephone work, and gravity batteries have long done good service for telegraphic purposes.

But when it comes to developing any considerable amount of actual power, then the limitations become apparent. When we remember that battery electricity will certainly cost in practice 50 cents per horse-power hour, since the materials alone cost 25 cents, and that dynamo electricity only cost 2 cents per horsepower hour, the claims of some primary battery electric lighting promoters show up in their true light. As a luxury, of course. it makes very little difference what it costs, but even then people soon tire of paying very ligh prices for that kind of a luxury. For small electric lighting and small power in special cases batteriss are useful, particularly where no other source of current is available. A physician or dentist to whom a horse-power hour may be worth hundreds of dollars could almost afford to use a chloride of silver battery and throw away the silver.

Mr. Crocker:--I do not wish to be understood as entirely skeptical in the matter of primary batteries. As I have said, the possibilities are almost infinite, but there are certain facts which cannot be overcome, which might as well be looked at straight in the face in the beginning, as after the company is formed and the failure occurs. There are certain legitimate applications of primary batteries even in their present state of imperfection. For example, the Leclanché battery is very satisfactory for ringing electric bells and for telephone work-we do not need a dynamo for those purposes-and even for small power uses, although I have not yet seen the battery which will practically generate electricity for actual power purposes at a reasonable 
price. As a luxury a battery can be used, or for some very special purpose, like a dentist's or a physician's work, where a horse-power hour may be worth $\$ 1,000$. There one could afford to use the silver-chloride battery and throw away the silver. (Applause.)

\section{DISCUSSION.}

Dr. Moses:-I think that we are very much indebted to $\mathrm{Mr}$. Crocker for his able paper, and we cannot too highly laud the expenditure of time, the energy and self-abnegation devoted to preparing a paper of that character for the Institute. There are some questions he will permit me to ask him that will lead to others, and in that way to a useful debate. I notice that in this table D you have used chlorine, bromine and iodine for the three elements that you combine. Why did you select those whose atomic weights are perhaps less accurately determined, and which are not absolutely considered as elemental in their characer? Why did you not, perhaps, take oxygen or even carbon for the purpose?

Mr. Crocker:- In the first place, as I have said, oxygen pure and simple, does not combine directly with zinc in a battery. Free oxygen will dissolve only in the solution to a very limited extent, and it would, of course, be possible to use it, but only in a very delicate way. Whereas, bromine, chlorine and iodine will freely dissolve in the solution, and thus can be practically used in an elementary state. So far as the elementary character of bromine, chlorine and iodine is concerned, I have never heard it questioned before. If you mean that all so-called elements are not elements, and that hydrogen is really the only element, why, then, of course, these three go with the others, but, so far as I know, they stand on the same basis as carbon, oxygen and the rest; and, furthermore, they constitute a series, or family, of chemical elements. The results obtained are more clear and more instructive when a series of elements are used than when you take elements at random, such as the acids for instance, which are not exactly on the same basis. The real depolarizers are usually elements like chlorine, bromine and iodine. Chromic acid itself is not a depolarizer, it is the oxygen it contains. In that case it may be said that oxygen is employed as a depolarizer, but it is not free oxygen, it is in combination with chromide oxide, and therefore the question is complicated. It is, however, perfectly 
possible to apply these same principles to any other chemical combinations, but it makes a more difficult problem, and the results are less clear.

Dr. Moses:- The figures are very conscientiously given, and the statement which $\mathrm{Mr}$. Crocker makes that he puts down here a negative quantity simply because his galvanometer shows it, is a very acceptable statement, because he shows what he gets. Even the most inaccurate observations or results, if the methods are given, prove of equal value with the most accurate, as we recollect in the case of Vauquelin's analysis in the beginning of this century, though done in the most imperfect way, according to present methods, are very valuable, because he gives an account of how he did it. But there is a series of facts that are brought out by an inspection of the table and that rather tend to point to the moral that chlorine is itself not an element. I would like to recall to Mr. Crocker's attention the fact that the very discoverer of chlorine doubted its elemental character for a very long time, and it is to-day a mooted question whether it is a simple element. You have in that table a series of comparisons in which you find, with but one exception, that the determination is less than the calculated one. I will read them: $3.24,3.1 ; 2.9,2.11 ; 2.19 ; 2.3$, $2 ; 1.75,1.6 ; 1.64,1.43 ; 1.57,1.43 ; 1.71,1.61 ; 1.76,1.63 ; 1.4$, $1.32 ; 1.25,1.11 ; 1.3,1.22 ; 1.3,1.21$. That shows of itself there is a certain law there; it shows that perhaps you should assume a lower chemical equivalent for chlorine.

Would you also tell us why you prefer not to determine accurately the amount of water that you used for solution? Don't you find, since water is essential, that its chemical equivalent and its relations to the substances in solution should be just as accurately determined, though we are inclined to consider a solution is not a chemical combination? Still, for these purposes the elements go through combinations through the solution. Therefore, why isn't it essential to determine the water?

Mr. Crocker :- The water is merely a medium for the action to take place in; that is really the chemical fact. Of course I could put there, in the case of the weights, about how much water an ordinary solution would require; but that really would be merely guesswork. The best you could do would be to find when you obtained the maximum results, and that would be a very difficult question, but I find that it makes very little difference in electromotive force whether a strong or a weak solution 
is used. It does make some difference. The stronger the solution, the less the electromotive force. The difference amounts to about $5 / 100$ or $1 / 10$ of a volt. This is because there is more tendency for the metal to go in solution when the latter is weak; whereas if the solution is already satisfied it has less affinity for the metal. That is the way I explain the fact. I intended to bring out this point in my paper, but it involves another series of experiments, and the ones I have given were all that I had time to undertake.

Dr. VANDER W WYDE:-Is it not the fact that a certain concentration of a solution gives the least resistance? We all know that, for instance, a mixture of sulphuric acid and water of a certain proportion is the best conductor. If we increase the water or the sulphuric acid the resistance becomes greater.

In the meantime, Mr. President, while I am up, I cannot refrain from paying a compliment to $\mathrm{Mr}$. Crocker (applause) for his very useful labor, It was just the thing that was needed, and I rejoice that the young man goes in the right direction. It is an investigation in which I had been engaged myself some years ago, intending to publish some data, but other business intervened and I found the field so extensive that I despaired of making it as complete as Mr. Crocker has done. (Applause.)

I wish to make one remark about the function of water in the battery. I would like to hear Mr. Crocker's opinion about a widely adopted theory that the water is the main agent in the batteries-that it is the decomposition of the water which does the work; that the oxygen of the water combines with the zinc and that hydrogen is developed, and a layer is formed which is the cause of polarization, and in order to get rid of that hydrogen the depolarizer's are applied. I would like to hear Mr. Crocker's opinion about that theory.

Mr. Crocker :-As regards the function of the water in the battery it is one of those metaphysical points. (Laughter.) The water may act and give up its oxygen. The hydrogen may give up the oxygen on one side and turn around and get more on the other side. So far as I can see, it is water all the time. It is not changed, and it acts as a transmitter; that is the most it does. It acts as a vehicle. But after the action is over, there is just as much water there as there was before, unless it has evaporated; and in fact some chemical actions involved in batteries produce water, and in that case there would be more water at the end of 
the action than there was at the beginning. Therefore, it could hardly be said that it was used up. Furthermore, the action would take place exactly the same in the anhydrous state, whenever it is possible to get that state. For example, with a fused salt the action is exactly the same. The zinc would combine with chlorine in fused chloride of zinc, as I have myself proved by experiment. and would give substantially the same electromotive force as it does in the presence of water. Water is merely a means of getting a liquid conductor, which it is necessary to have as an electrolyte. An electrolyte must be a liquid, and you can obtain the liquids by fusing a solid electrolyte, or by dissolving a solid electrolyte. Therefore I always look upon the water merely as a means, or medium, in which the action takes place.

Dr. VANDER WEYDE:-But the question naturally follows that if the zinc is oxydized by the oxygen what becomes of the hydrogen at the point of contact with the oxygen? Then there is more than a mere vehicle. We see that the hydrogen is developed at the platinum or silver plate.

Prof. Nichols:-I would like to supplement Mr. Crocker's statement by an observation in reference to the behavior of iron, and I presume what is true of iron will be true of other metals which form two salts. If you take iron and platinum in a solution which will produce a ferric salt, and let the cell stand, so that the iron in solution becomes surrounded with a film of its own salt, then the ferric action will gradually cease and ferrous action will take place. After the cell has stood, the electromotive force will rise about one-fifth, and you can instantly restore it to the condition it had at first. If you take a porous cell and separate the iron and platinum, put the oxidized solution in connection with platinum and then around the iron something which will produce the ferrous salt, you will find that that battery has about one-fifth more electromotive force than in the case of the ferric combination. It seems as though a more successful battery ought to be made with iron producing the ferrous salts. You gain almost enough to make up the difference between iron and zinc; but the behavior of iron is very unsatisfactory, and the reasons for it are not always very clear. It seems as though oftentimes it was due to the formation of oxidized films which run the resistance of the cells up to an enormous height. I have known the resistance of bichromate cells with iron positive plates to run up to several hundred ohms in the course of an hour or so by the formation, apparently, of an insoluble film of some form of iron 
which was almost a non-conductor. Perhaps iron, if worked out patiently, might give us a very cheap metal for a pole of a battery which would reduce the cost of galvanic electricity very considerably.

Dr. VANDER Weyde:-I want to say in respect to silver being an electro-negative, that Mr. Crocker is perfectly right in that.

Dr. Moses:-The remarks of Prof. Nichols recall to my mind some experiments which he perhaps has overlooked, but which he made quite a number of years ago, in which he used, if my memory serves, zine in a sulphate of copper solution, where the change of temperatures produced considerable variations. I would like to inquire whether that was not due to the formation of salts of variable solubility around the electrode.

Mr. Nichols:-It might very easily be.

Mr. Mallloux:-I would like to ask what appears to be a somewhat pertinent question in view of the discrepancy observed between the calculated and determined electromotive force, and that is as to the standard which Mr. Crocker used; what value he accepted for it, and upon what authority, so that we may know what kind of a volt he employed.

Mr. Crocker:-That is an important point, of course, because everything depends upon it. I used constant Daniell cells, two independent ones set up separately, with chemically pure sulphate of zinc and sulphate of copper, and chemically pure metals; the solutions were half saturated. Then I further checked the results by two electromotive forces which I happened to know and had previously determined very many times, and those are the bromide and the iodide combination of zinc. The former combination in itself is an excellent standard cell, that is, free bromine and zinc. It gives an electromotive force of 1.79 volts. That is the result, I suppose, of a thousand experiments carried on with a certain object. Therefore in going through my experiments when I came to the combination zincbromide and found that it gave an electromotive force of 1.79 volts, I felt perfectly at home, because I had been there so often before, and it corroborated by standard. Then the combination of zinc and chlorine, 2.11 volts has also been very frequently determined. In the case of the Upward (zinc-chlorine) battery, which came out about a year and a half ago in England, the published electromotive force was 2.11 volts. So there were several corroborative facts. So far as my experience goes, a standard Daniell cell does not vary very much in electromotive force. 
Prof. Thomson:-I would like to say just one word on thi subject. It has been probably a common experience of those having Daniell cells in operation, that, if the solution is not kept up to a high degree of strength, oftentimes the upper part of the copper will be eaten out, and an electrolytic deposit of the copper made in the lower part of the cell whero the solution is strong; or, in other words, here is an indication of a difference in the volts which carries on a sort of plating action on the copper plate itself. Whether this be due partly to the effect of the acid, or that the solution comes through from the porous cup and floats on top, causing a difference in the electrolytic condition of the fluids alone, setting up current, I do not know. But it recalls to my mind an observation several years ago on the effect of simple heating of the solution by putting at the lower part of a test tube a little spiral of eopper wire and carrying out a connection by an insulated wire from the spiral, filling up the test tube partly with sulphate of copper solution ; putting another little spiral near the top of the fluid, and then heating, we find a difference of voltage, and it amounts, I think, to something over one-tenth of a volt, or rather, something over one-twentieth of a volt, if I remember the result of the experiments correctly; showing that a solution of the copper will take place in the hot liquid, and a deposition of the copper in the cold liquid. In other words, the hot liquid is more of a solvent than the cold, although it is a sulphate of copper solution throughout. Whether Mr. Crocker has taken into account the temperature of the solutions in making these tests I do not know.

Mr. Crocker:--I made the tests at the normal temperature. It did not vary 5 degrees from 68 ; I do not think it varied more than three or four degrees. What Prof. Thomson says about a hot liquid giving electromotive force with a cold liquid, as it were, is true. In fact, Mr. Bradley has a battery which works on that principle, giving quite an electromotive force; I could not say exactly what, but quite a fraction of a volt, and it depends, to a certain extent, upon the heat of the solution; and that is a very interesting and possibly a productive field for investigation.

Prof. Thomson:-There is another point and then I am through. It is probably well understood nowadays that all the elements are not to be considered as real elements as we find them. I do not mean that they are decomposable into hydrogen, 
although I think that quite possible, and perhaps even to a far more primitive condition than hydrogen, if we could use forces which we have not at hand-I mean the celestial forces. I mean that each particle of copper known to us is a combination of copper with copper; that the atom really forms a molecule which is a real compound. Two atoms or more atoms may be found united, but it will certainly take something to decompose thoce molecules, even though they be combinations of the same atoms. I am struck with the results obtained with aluminium in the work of Mr. Crocker. We find actually that this metal, so hard to get at, is really capable of giving an electromotive force less than zinc; so that it would seem as though by the proper use of zinc in some way or other we might separate aluminium. In other words, its electromotive energy is very much less than zinc, and in some cases not very much different from iron. In the recently developed reduction of aluminium we find that carbon at high temperature reduced it with comparative facility, and it may be that after all, we have only to find, something which will fluidize or liquify the aluminium, and we would then find that even common materials like zine or iron would separate from these combinations.

Mr. Crocker :-In regard to aluminium, the same thing struck me that Prof. Thomson points out. By my experiments aluminium is apparently less electro-positive than zinc. I do not think that this is actually the fact. I think there is some loss of electromotive force which occurs. In fact the calculated results are higher than those of zinc, and it may be that with aluminium there is a formation of insoluble compound on the plate. I am quite certain that my observed electromotive forces, although they are the actual electromotive forces given by a good piece of aluminium, are lower than the theoretical and lower than the possible electromotive force.

Dr. VANDER Weyde:-It may be useful to state here that twenty years ago I attempted to substitute aluminium for platinum in the Grove battery, on the principle that nitric acid does not attack platinum. The result was negative. I got scarcely any current at all. It appeared that aluminium had not the power to decompose the nitric acid and produce the nitrous acid fumes as with platinum in the Grove battery. It was a very carefully made experiment and impressed me very much.

Note.-The continuation of the Transactions of the General meeting wlll follow in the July 